\title{
Natural radioactivity assessment by gamma spectrometry in some commercially-used granites from Paraná State, Brazil: Preliminary results
}

\author{
A.O. Ferreira and B.R.S. Pecequilo \\ Environmental Radiometric Division, Instituto de Pesquisas Energéticas e Nucleares \\ Av. Prof. Lineu Prestes, 2242, Cidade Universitária, 05508-000 São Paulo, SP, Brazil
}

\begin{abstract}
Natural radioactivity concentrations in commercially-used granites from Paraná state, Brazil, were measured in order to estimate the potential radiological hazard to mankind due to granite as an ornamental building material through the ${ }^{226} \mathrm{Ra},{ }^{232} \mathrm{Th}$ and ${ }^{40} \mathrm{~K}$ activities concentrations measured in several samples by high-resolution gamma-ray spectroscopy. Preliminary results, without considering samples selfattenuation, show activities concentrations varying from $4 \pm 1 \mathrm{~Bq} \mathrm{~kg}^{-1}$ to $79 \pm 3 \mathrm{~Bq} \mathrm{~kg}^{-1}$ for ${ }^{226} \mathrm{Ra}^{2} 7 \pm 1$ $\mathrm{Bq} \mathrm{kg}{ }^{-1}$ to $142 \pm 6 \mathrm{~Bq} \mathrm{~kg}^{-1}$ for ${ }^{232} \mathrm{Th}$ and $214 \pm 14 \mathrm{~Bq} \mathrm{~kg}^{-1}$ to $1626 \pm 77 \mathrm{~Bq} \mathrm{~kg}^{-1}$ for ${ }^{40} \mathrm{~K}$. All results are within the range of literature values for similar rocks. Further, the annual effective dose, the radium equivalent activity and the external and internal hazard indexes will be assessed.
\end{abstract}

\section{INTRODUCTION}

Naturally Occurring Radioactive Materials (NORM), are present in virtually living or inanimate everything in our planet [1]. There are two mainly sources of NORM: cosmogenic and terrestrial radiations. The main external source of background radiation exposure of the population are the terrestrial radionuclides like the single occurring radionuclides as ${ }^{40} \mathrm{~K}$ and the radionuclides of the ${ }^{238} \mathrm{U}$ and ${ }^{232} \mathrm{Th}$ decay series, with half-lives of the same order that the age of the earth [2].

The main external exposure to humans by natural radionuclides is due to raw materials that are used in civil construction, houses and buildings. The indoor exposure is due mainly to granitic rocks that are used in raw material or haw covering material (ornamental). Many kinds and shapes of rocks may by used in a building, as aggregate, covering material or ornamental.

The natural radioactivity in rocks depends on their nature, generally higher concentrations are more common in igneous rocks than the sedimentary and metamorphic, where the main contributing radionuclides are the ${ }^{238} \mathrm{U},{ }^{232} \mathrm{Th}$ e ${ }^{40} \mathrm{~K}[3]$.

The igneous rocks show a considerable variation depending on the chemical, mineralogical, petrographic and structural characteristics. Therefore, the abundance of uranium and thorium in these rocks, besides the initial concentration, depends mainly on the history of post-crystallization of the rocks.

In Brazil, the geology of the Paraná state is basically composed by sedimentary and igneous rocks, respectively from Paraná Sedimentary Basin and Crystalline Shield (Fig. 1). The crystalline shield is composed of igneous and metamorphic rocks with ages ranging from Archean to Proterozoic. The oldest rocks, with high metamorphic grade, outcrop in the southeastern portion, and the low metamorphic grade at the north-northwest. In the Proterozoic and Cambrian, early Paleozoic, magmatic manifestations originated the granitic rocks [4]. This Crystalline shield is, therefore, the most important source of rocks to building materials in the state, both as aggregates, raw material for cement industry and as ornamental rocks. This geographic region represents almost 65\% of the total mineral production in Parana, with the Metropolitan Region of Curitiba (RMC) (Fig. 2) being responsible for approximately $70 \%$ of this value or $45 \%$ of the total mineral production [4]. 


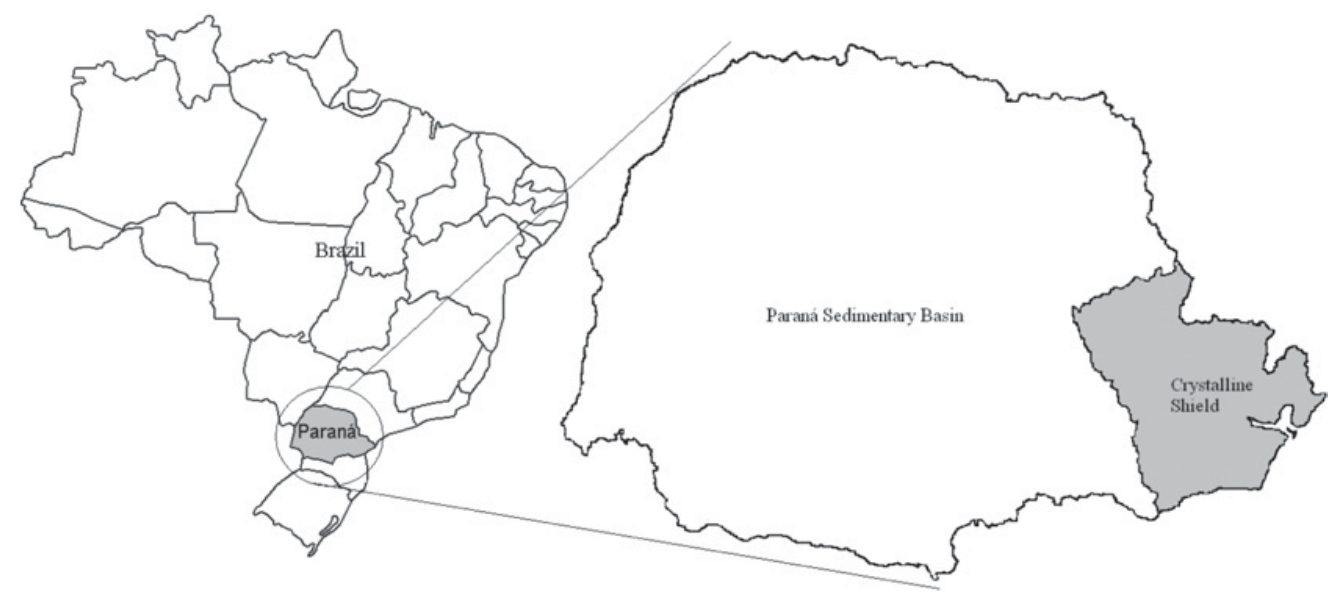

Figure 1. Paraná Geology.

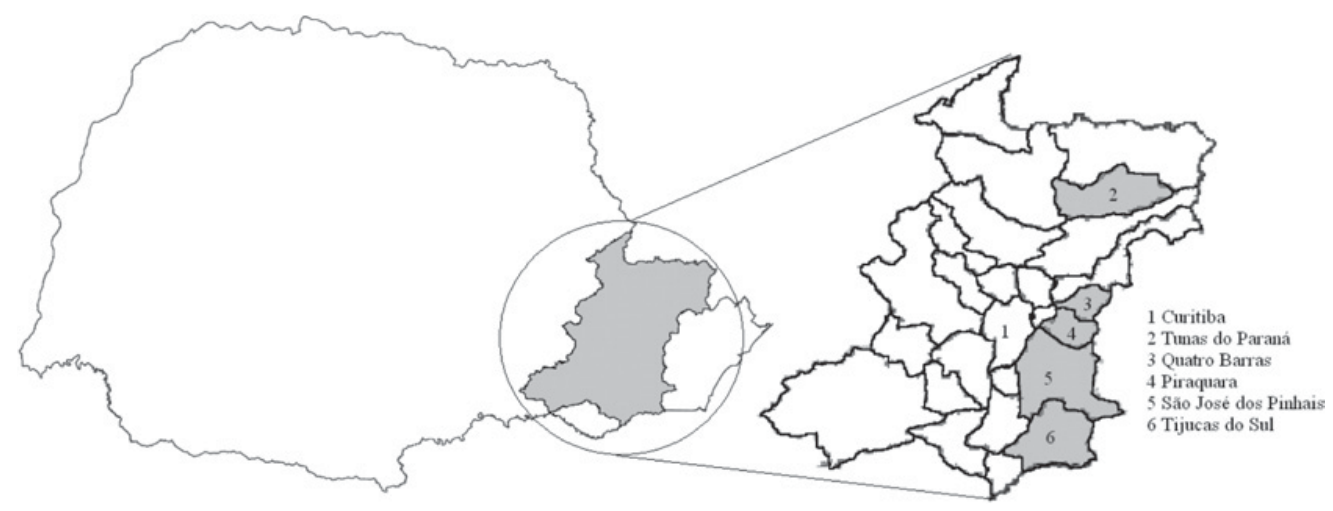

Figure 2. Major cities with geological occurrence of granites.

\section{MATERIAL AND METHOD}

\subsection{Sample collection and preparation}

Eighteen granite samples (Tab. 1) were obtained from commercial shops and factories close to their quarry (outcrop of origin) in the Metropolitan Region of Curitiba (RMC) (Fig. 2), where major cities producing granites are Tunas do Paraná, Quatro Barras, Piraquara, São José dos Pinhais and Tijucas do Sul [4].

Each sample was collected in the final commercial shape of a $10 \mathrm{~cm} \times 10 \mathrm{~cm}$ square, weighting approximately $1 \mathrm{~kg}$. All samples were pulverized and sealed in a 100-mL HDPE flat-bottom cylindrical flasks with screw cap and bubble spigot and measured in triplicate, after a 4 weeks ingrowth period for radioactive equilibrium in the ${ }^{238} \mathrm{U}$ and ${ }^{232}$ Th series [5].

\subsection{Gamma-Ray Spectrometry}

The samples were measured by high-resolution gamma-ray spectrometry with a coaxial high-purity germanium detector (HPGe) of $15 \%$ relative efficiency and resolution of $1.9 \mathrm{keV}$ for the gamma-ray 
Table 1. Granite samples from the major cities region.

\begin{tabular}{ccc}
\hline ID & Type & Trade name \\
\hline GBD & Granite & Bege Dunas \\
GPG & Granite & Paraná Green \\
GVV & Granite & Verde Vulcano \\
GIM & Granite & Imperador \\
GVI & Granite & Vermelho Itaipu \\
GVD & Granite & Verde Dunas \\
GCI & Granite & Café Imperial \\
GSFG & Granite & Sea Foam Green \\
RCB1 & Rhyolite & Riolito Castro Brita 1 \\
RCB2 & Rhyolite & Riolito Castro Brita 2 \\
BB1 & Basalt & Basalto Brita 1 \\
GBP & Granite & Branco Paraná \\
GCA & Granite & Cerro Azul \\
GJI & Granite & Jade Imperial \\
GRC & Granite & Rosa Curitiba \\
GVB & Granite & Verde Boreal \\
GVM & Granite & Verde Mar \\
GVT1MM & Granite & Verde Tunas \\
\hline
\end{tabular}

transition of $1.33 \mathrm{MeV}$ of ${ }^{60} \mathrm{Co}$, with conventional electronics and an a 919 ORTEC EG\&G Spectrum Master 4k-multichannel analyzer. All spectra were analyzed with the InterWinner 6.0 software [6].

The activity concentration of a single transition was calculated as:

$$
A\left({ }^{A} X\right)=\frac{C(E)}{P_{\gamma}(E) \cdot \varepsilon(E) \cdot m \cdot t}
$$

Where $\mathrm{A}\left({ }^{\mathrm{A}} \mathrm{X}\right)$ is the activity of the considered transition of the isotope ${ }^{\mathrm{A}} \mathrm{X}$ in the sample with mass $\mathrm{m}$; $\mathrm{C}(\mathrm{E})$ is the net number of counts obtained for the gamma transition with energy (E) emitted by ${ }^{\mathrm{A}} \mathrm{X}$ during the counting time $\mathrm{t}$, and $\mathrm{P} \gamma(\mathrm{E})$ and $\varepsilon(\mathrm{E})$ are, respectively, the probability of emission and the detector efficiency for the considered gamma transition.

For each sample, the activity of ${ }^{40} \mathrm{~K}$ was calculated through its $1461 \mathrm{keV}$ single gamma transition, the activity of ${ }^{226} \mathrm{Ra}$ by the weighted mean of the ${ }^{214} \mathrm{~Pb}$ gamma ray transition of $295 \mathrm{keV}$ and ${ }^{214} \mathrm{Bi}$ gamma ray transition of $609 \mathrm{keV}$ and the activity of ${ }^{232} \mathrm{Th}$ by the weighted mean of the ${ }^{228} \mathrm{Ac}$ gamma ray transition of $908 \mathrm{keV}$ and ${ }^{212} \mathrm{~Pb}$ gamma ray transition of $239 \mathrm{keV}$. The final result was the mean of the triplicate measurements.

The background radiation was obtained with a 100-mL HDPE flat-bottom cylindrical flask with screw cap and bubble spigot filled with ultrapure water and the efficiency calibration curve was performed with a multinuclide standard aqueous solution in the same geometry as all measured samples.

\section{RESULTS}

The preliminary results obtained for the activity concentration of ${ }^{226} \mathrm{Ra},{ }^{232} \mathrm{Th}$ and ${ }^{40} \mathrm{~K}$ in the eighteen samples, without self-attenuation correction, are presented, respectively, in Figs. 2, 3 and 4.

Almost all results for the granites originated from the Paraná State are within the activities concentrations ranges obtained by Moura for similar igneous rocks from Sao Paulo State and Southern Minas Gerais State. 


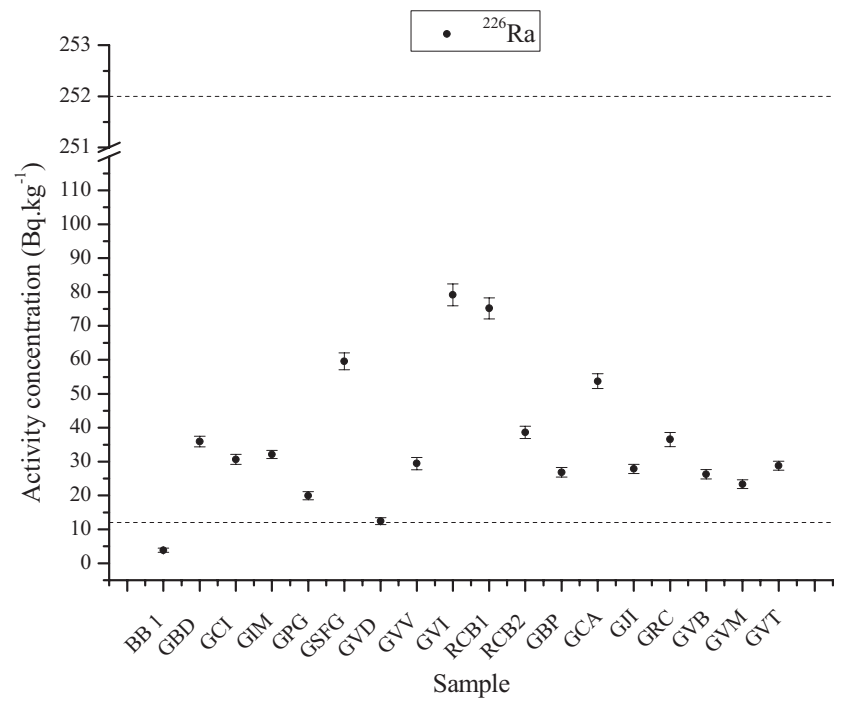

Figure 3. Activities concentrations of ${ }^{226} \mathrm{Ra}_{\text {in }} \mathrm{Bq} \mathrm{kg}^{-1}$ for the Paraná granites analyzed samples (The dashed lines represent the minimum and maximum literature values found by Moura [3]).

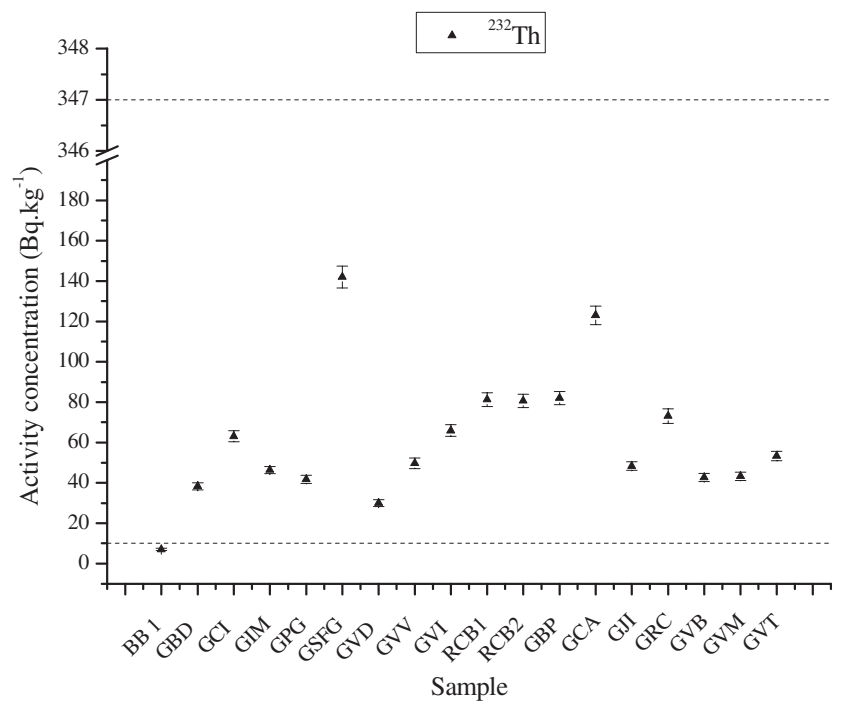

Figure 4. Activities concentrations of ${ }^{232} \mathrm{Th}_{\text {in }} \mathrm{Bq} \mathrm{kg}^{-1}$ for the Paraná granites analyzed samples (The dashed lines represent the minimum and maximum literature values found by Moura [3]).

\section{CONCLUSIONS}

The results show that the activities concentrations of the granites samples from the Paraná Crystalline Shield lie into the literature values ranges for natural radioactivity concentrations for geological similar rocks. As those granites are often used as ornamental building materials, further assessments of the annual effective dose, the radium equivalent activity and the external and internal hazard indexes must be considered. Also, as the samples apparent densities are around $1.5 \mathrm{~g} . \mathrm{cm}^{-3}$ and the detector 


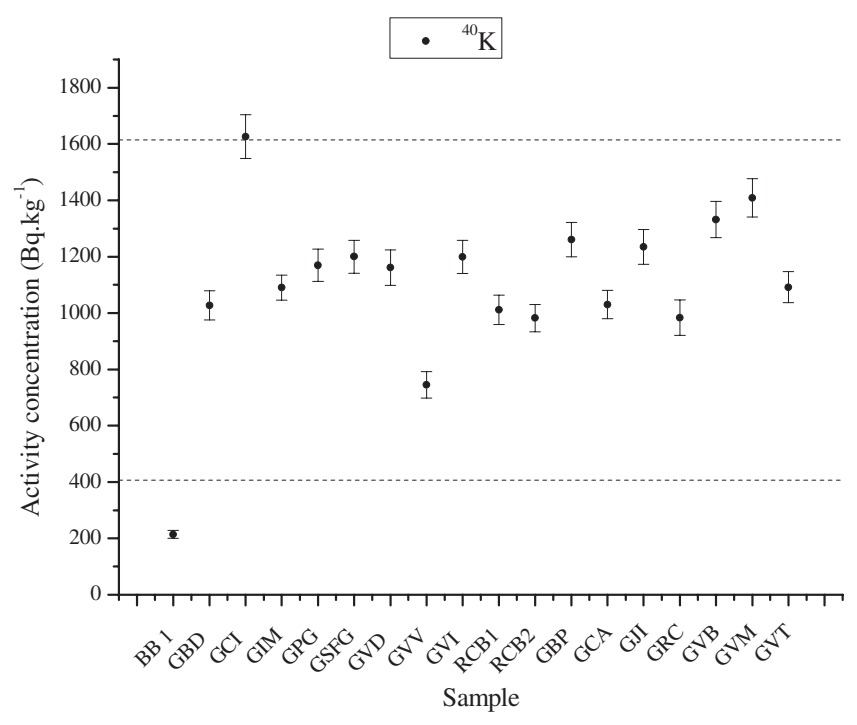

Figure 5. Activities concentrations of ${ }^{40} \mathrm{~K}_{\text {in }} \mathrm{Bq} \mathrm{kg}^{-1}$ for the Paraná granites analyzed samples (The dashed lines represent the minimum and maximum literature values found by Moura [3]).

efficiency was determined with an aqueous radioactive solution, self-attenuation for each sample will be determined and, possibly, higher concentrations values can be obtained.

\section{Acknowledgements}

This work was supported by CNEN (National Nuclear Energy Commission)

\section{References}

[1] Ronald L. K., Appl. Radiat. Isot Vol 49 (1998) 149-168.

[2] UNSCEAR - 2000, United Scientific Committee on the Effects of Atomic Radiation (UNSCEAR), The 2000 Report to the General Assembly with scientific Annexes. New York: United Nations, 2000.

[3] Moura, C. L., Radioatividade natural e emanação de Rn-222 em rochas ornamentais provenientes de diferentes series magmáticas, UNESP Rio Claro, Rio Claro, (2005) Tese de Doutorado, PósGraduação em Geologia Regional, 28-40.

[4] MINEROPAR, available at www.mineropar.pr.gov.br, accessed on 19/05/10.

[5] Evans, Robley, D. The Atomic Nucleus. New Delhi: TATA MCGRAW-HILL, 972 p. (1979).

[6] INTERWINNERTM 6.0 MCA Emulation, Data Acquisition and Analysis software for Gamma and Alpha Spectroscopy IW-B32 2004. ORTEC. Oak Ridge, TN, USA. (2004). 